\title{
WOMEN, THE VATICAN, AND HOPE FOR THE FUTURE: AN ECUMENICAL QUAGMIRE ${ }^{1}$
}

\author{
Clint Le Bruyns \\ Department of Systematic Theology and Ecclesiology \\ Stellenbosch University
}

\begin{abstract}
The prevailing position against women's ordination to the ministerial priesthood in the Roman Catholic Church presents itself as an ongoing ecumenical dilemma within and beyond its ecclesial borders. This paper provides an overview of the 'official' position of Rome in teaching and defending the church's view against the ordination of women, even in the midst of great dissent among its members. Then it proceeds to lay a basic foundation for legitimately and respectfully offering an ecumenical contribution. Finally it considers several challenges that confront the ecumenical community in engaging an ecumenical response.
\end{abstract}

I was once invited to the home of some acquaintances for dinner. When all the guests had arrived, the hostess invited us into the dining room. As I entered the room, I noticed with astonishment that there was a horse on the table. I caught my breath but didn't say a word.

I was the first to enter the room, so I was able to observe the other guests. They responded much as I had - they entered, saw the horse, gasped and stared, but said nothing.

It was cramped sitting at the table and trying to avoid the horse. Everyone obviously was ill at ease. We were all trying not to look at the horse, yet unable to keep our eyes off it.

I thought several times of saying, "Look, there's a horse on the table." But I didn't know the host and hostess well, and I didn't want to mention something that might embarrass them. After all, it was their house. Who was I to say they couldn't have a horse on the table?

I could have said that I didn't mind, but that would have been untrue - its presence upset me so much that I enjoyed neither the dinner nor the company. I excused myself early and went home.

I later learned that the host and hostess were hoping the dinner would be a success despite the horse. But both they and the other guests had thought about little else than the horse and how to avoid mentioning it.

An ancient Sufi parable

\section{The 'Official' Position of Rome on Women's Ordination}

Almost three decades ago, in the wake of the decision by U.S. Episcopalians to ordain women, the Vatican released a document that now serves as the point of departure for any current discussion of the Roman Catholic position on women's ordination. On October 15, 1976, Paul VI issued an apostolic letter titled Inter Insigniores ("Declaration on the Question of the Admission of Women to the Ministerial Priesthood"), which effectively

1. An adapted version of a paper delivered at the congress of the Theological Society of Southern Africa on "Gender and Theology in Africa" held at the University of Pretoria on 19 June 2003. I am particularly grateful for the constructive responses to the presented paper by Nico Koopman and Susan Rakocsy.

2. As told in Manning (1999:153-54). 
ruled out women's ordination. The opening line of the document stated: "The Catholic Church has never felt that priestly or episcopal ordination can be validly conferred on women" (§1). What followed was merely an elaboration and substantiation of that thesis, contending that the essential reason against women's ordination rested with the church's intention "to remain faithful to the type of ordained ministry willed by the Lord Jesus Christ and carefully maintained by the Apostles" (§1).

Advocacy for women's ordination nevertheless continued after 1976 with bishops, priests, and laypeople calling for a reversal of the Vatican's declaration. It is noteworthy that still at this time the doctrine of an exclusively male priesthood did not rank very high in importance in the Roman Catholic 'hierarchy of truths'. ${ }^{3}$ While it was indeed a traditional practice followed in the church, it was not a teaching accorded the status of a truth of revelation (as would be the Incarnation or the Resurrection), so it rested on a much lower plain of authority (than the divinity of Christ, for example). ${ }^{4}$ It is understandable, therefore, why advocates of women's ordination pressed ahead in anticipation of a potential change of mind in the church.

Such expectations were dealt a heavy blow, however, when John Paul II released his apostolic letter on May 22, 1994, titled Ordinatio Sacerdotalis ("On the Reserving of Priestly Ordination to Men Alone"), which served as the Vatican's deafening thunderclap on advocacy efforts for women's ordination. Only four paragraphs in length, the pope's remarks were intended to be crisp and clear. Once again, the church's official position appeared in the opening statement: "Priestly ordination, which hands on the office entrusted by Christ to his Apostles of teaching, sanctifying and governing the faithful, has in the Catholic Church from the beginning always been reserved to men alone" $(\S 1)$. The most hard-hitting remarks, though, were saved for last (\$4):

Although the teaching that priestly ordination is to be reserved to men alone has been preserved by the constant and universal Tradition of the Church and firmly taught by the Magisterium in its more recent documents, at the present time in some places it is nonetheless considered still open to debate, or the Church's judgement that women are not to be admitted to ordination is considered to have a merely disciplinary force.

Wherefore, in order that all doubt may be removed regarding a matter of great importance, a matter which pertains to the Church's divine constitution itself, in virtue of my ministry of confirming the brethren (cf. Lk 22:32) I declare that the Church has no authority whatsoever to confer priestly ordination on women and that this judgement is to be definitively held by all the Church's faithful.

The case was closed! Women's ordination in the Roman Catholic Church was categorically forbidden, including its advocacy. The Vatican statement declared this position to be part of "the Church's divine constitution" and a definitive teaching. The pope had now

3. What this means, in the order of beliefs in Roman Catholic doctrine, is that some truths are more important than others, thus requiring deeper assent by the faithful. It is also worth mentioning that the more elevated a teaching is in the 'hierarchy of truths', the more difficult it is for the church to change it. For a helpful explanation of this expression, see Tom Stransky, "Hierarchy of Truths" in Nicholas Lossky, et al (eds.), Dictionary of the Ecumenical Movement, 2nd Edition (Geneva: WCC, 2002), 519.

4. On the teaching of the exclusively male priesthood, it would be more accurate to label it a doctrinal conclusion derived from revelation, according to the ordering of the church's web of beliefs. Nevertheless, in the light of its lower ranking in importance, there was no reason to rule out a potential change of mind on the question of women's ordination in the future. 
moved the prohibition to a higher level in the 'hierarchy of truths', elevating it to a central place in the church's teaching, out of reach in regard to any prospect for change. ${ }^{5}$

Then, in January 1997 the Vatican released a book titled From "Inter Insigniores" to "Ordinatio Sacerdotalis" that reinforced its case through a comprehensive overview of its position. The ban on women's ordination, if rejected, did not imply heresy, explained Cardinal Joseph Ratzinger in a later interview, but it was clearly erroneous and incompatible with the faith (Allen 2000:187). ${ }^{6}$ More was still to come, when in May 1998 the importance of such a prohibition was underlined yet again in an apostolic letter titled $A d$ Tuendam Fidem ("To Defend the Faith"), which placed this ban in a category of beliefs in which certain "definitively held" teachings were raised to the level of infallibility, resulting in a sliding scale of penalties for its denial that ranged from admonition to excommunication.

This notwithstanding, the proponents for women's ordination continued their discussions and efforts during and after this period, much to the exasperation of the Vatican. In 1995 in Austria and Germany, a petition for reform in the church garnered almost three million signatures, with women's ordination among its five key demands (Allen 2000:181). In 1999 a synod in the Montreal diocese voted to carry a message to Rome that it might be time to consider ordaining women (2000:181). In March 2002 a letter was sent to the Vatican by two giant German Roman Catholic women organisations - the Katholische Deutscher Frauenbund and the Katholische Frauengemeinschaft Deutschlands (which have a combined membership of over one million women) - requesting recognition of women's ordination to the diaconate (St Leger 2003:14).

According to former priest and veteran advocate for women's ordination, John Wijngaards, dissent on this matter has strengthened. He claims, based on research findings in 1999, that 86 percent of Roman Catholic parish clergy and their parish councils in the Netherlands firmly support women's ordination. Moreover, studies in Australia, Canada, Germany, Ireland, Italy, Portugal, Spain and the United States, put general support among Catholics at around 70 percent (Wijngaards 2003:15).

Still, the Vatican is irrepressible on the matter, engaging in a 'shock and awe' offensive against any dissenting voices among its members. It has kept theological statements back from publication, scholarly literature has been scrutinised and its authors investigated (cf. Allen 2000:182), ${ }^{7}$ ambitious academics have been dismissed from their teaching duties (cf. 2000:185), ${ }^{8}$ and the ban on continuing the debate reinforced in various ways (cf. 2000:185-

5. For resourceful information around the status of Ordinatio Sacerdotalis as a church teaching, and subsequent discussions, see Allen (2000), 185-87.

6. Ratzinger noted that heresy implied that a denial of a revealed truth had occurred but, since the ban on women's ordination was a doctrinal conclusion derived from revelation, those who denied it were excluding themselves from communion with the church. These dissenters were, in other words, de facto excommunicated.

7. As just one case in point, an investigation was initiated by Cardinal Ratzinger and opened by the doctrinal committee of the U.S. bishops' conference in the 1980s to scrutinise Richard McBrien's book Catholicism. According to John Allen, one of Cardinal Ratzinger's concerns rested with his impression that church teaching on women's ordination and contraception might change. For insight into the Vatican procedures for investigating the writings of theologians, see Reese, Thomas J, Inside the Vatican: The Politics and Organisation of the Catholic Church (London: Harvard University Press, 1996), 252ff.

8. The first victim, following the prohibition of Ordinatio Sacerdotalis, was Mercy sister Carmel McEnroy who was dismissed in May 1995 by St. Meinrad's Seminary in Indiana, USA. She was one of 1,000 Roman Catholics nationwide who formally petitioned John Paul II to reopen the debate on women's ordination. 
87), all in the attempt to preserve the church's 'official' doctrine of ministry. ${ }^{9}$ And yet the clamour for women's admission to the ministerial priesthood continues in various ways, albeit silently or surreptitiously for many in the church, and not without fear of reprisal. ${ }^{10}$

\section{Foundations for Engaging with Rome}

Having set the scene for how the question of women's non-admission to the ordained ministry was taught, affirmed, resisted, and defended in the Roman Catholic setting, I now wish to place the issue in its wider ecumenical milieu. The position of Rome demands an ecumenical response, grounded on several methodological assumptions that make it both possible and necessary to provide a critical and constructive contribution in this regard. After all, what right do I have as 'a guest' at 'the dinner table' in 'someone else's house' to talk to 'my host and hostess' about 'the horse on the table' that we just cannot ignore?

\subsection{Assumption 1}

\section{The non-admission of women's ordination lies within the realm} of ecumenical theology

As churches we uphold different understandings of the ordained ministry, which the 1982 Lima document Baptism, Eucharist and Ministry emphasised at great length in its ministry section (cf. M7-55). While a theological consensus statement on the ordination of women is not included in the text per sé, some attention is given to it by way of a brief commentary (cf. M18) in which its ecumenical nature and import is highlighted. In the past century various churches, including the Anglican Communion itself, ${ }^{11}$ underwent shifts and changes in the area of women's ordination. The prevailing position of the Roman Catholic Church, therefore, features today as a classic theological topic of interest and relevance for the wider community of Christians. It cannot be viewed as a mere Roman Catholic issue; far from it, it is a catholic matter.

\subsection{Assumption 2}

\section{The non-admission of women's ordination lies within the realm}

\section{of ecumenical dialogue}

The position of the Vatican is not only of interest to non-Roman Catholics as an ecumenical subject, but it is especially of great concern to us as an ecumenical obstacle. A perusal of the array of bilateral dialogues between Rome and the Anglican and Protestant churches reveals the exclusion of women in ordained ministry as a serious stumbling block in our ecumenical relations. ${ }^{12}$ Once again, it is not a mere Roman Catholic issue; it is an ecumenical concern. ${ }^{13}$

9. By "official" I do not mean to imply that all Roman Catholics take this position against women's ordination, but that their bond of communion is bound up with their communion with the Holy See and the magisterium, who speaks on behalf of official Roman Catholic teaching.

10. The question of women's ordination is far from closed for many laypeople that choose to speak out in various Roman Catholic publications. For instance, in recent months there have been a steady number of letters to the editor and/or columns that relate directly or indirectly to the matter in the U.K.'s The Tablet. For example, see the following 2003 issues as apt cases in point: 11 January, 18 January, 25 January, 8 February, 15 February, and 24 May. In the April 2003 edition of the U.S.'s First Things publication, an article appears on "Ordaining Women: Two Views" - written by a Lutheran-turned-Roman Catholic and a Lutheran woman respectively.

11. See Tanner (1991:752-55).

12. In the international Methodist-Roman Catholic Dialogue, the Dublin Report of 1976 noted that while "The Roman Catholic Church, in keeping with her traditional practice, does not ordain women to the priesthood", 


\subsection{Assumption 3}

\section{The non-admission of women's ordination lies within the realm of ecumenical critique}

The path of ecumenism embraced by Rome at the Second Vatican Council (1962-1965) was deemed "irrevocable"14 and instantly positioned the church in a new relationship with the wider community of churches. Similarly, all churches that participate in the ecumenical sojourn are not lone rangers in the ecclesial world; on the contrary, they are now in a new relationship with one another in which involvement, feedback, and even criticism is both evident and necessary. Not in a hostile or self-serving or threatening manner, though, but as a 'gift'. Employing Margaret O'Gara's concept of the ecumenical 'gift-exchange', ${ }^{15}$ the

"Methodists can find no theological objection to the ordination of women. They hold that God has manifestly called women as well as men to the ministry of word and sacraments; therefore they ordain them." [See "Dublin Report, 1976" in Harding Meyer and Lukas Vischer (eds.), Growth in Agreement: Reports and Agreed Statements of Ecumenical Conversations on a World Level, Faith and Order Paper no. 108 (Geneva: WCC, 1984), §102.] Later, in their statement on "The Apostolic Tradition", the participants acknowledged again: "Methodists ordain women because they believe that women also receive the call, evidenced by inward conviction and outward manifestation of the gifts and graces and confirmed by the gathering of the faithful." [See "The Apostolic Tradition, Fifth Series 1986-1991" in Gros, Jeffrey, Meyer, Harding and Rusch, William G (eds.), Growth in Agreement II: Reports and Agreed Statements of Ecumenical Conversations on a World Level, 1982-1998, Faith and Order Paper no. 187 (Geneva: WCC, 2000), §96.] However, "Catholics do not ordain women, believing that they have no authority to change a practice that belongs to the sacrament of order as received in the Tradition of the church.” [Ibid., §97.]

In the international Reformed-Roman Catholic Dialogue, their statement "Towards a Common Understanding of the Church" merely highlighted a crucial difference concerning the ordained ministry that should not be overlooked, that of women's ordination: "In the Reformed churches, as in many other Protestant communions, it has become increasingly common in recent decades to ordain women without restriction to the ministry of word and sacrament." [See "Towards a Common Understanding of the Church, Second Phase, 1984-1990" in Gros, et al, §141.] However, a stronger tone was evident in the U.S. conversations, such as their statement on "Women in the Church". Here the participants lamented considerably over various injustices women faced in society and church, including the non-admission of women to ordination. They reasoned: "Since the Churches have need of all available human resources for carrying out their mission to mankind, it is unreasonable to deny ordination to women simply because women have not been admitted to ordination in the past. Several thorough theological investigations made in various Churches have found no Biblical, doctrinal, or theological obstacles to the ordination of women." [See "Women in the Church" in Joseph, A. Burgess and Jeffrey Gros (eds.), Building Unity: Ecumenical Dialogues with Roman Catholic Participation in the United States (New York: Paulist Press, 1987), 382.]

In the international Anglican-Roman Catholic Dialogue, we find the greatest emphasis compared to other conversations. In their 1979 Elucidation on their agreement on the nature of ministry, mention was made of women's ordination. Here the Anglican Communion was cognisant of the grave new obstacle women's ordination had presented for the Roman Catholic Church, but asserted that "the bishops concerned believe that their action implies no departure from the traditional doctrine of the ordained ministry." [See "Elucidation (1979) in Meyer and Vischer, §5.] In the U.S. dialogue's twelve-year report, they recognised the deeply divisive nature of women's ordination, but strongly recommended it as an area for further investigation. [See Burgess and Gros, §B.2.] A perusal of other documentation between the Holy See and the Archbishop of Canterbury would reveal the place of women's ordination in the ongoing discussions and relational strain of Anglican-Roman Catholic dialogue.

13. It must be acknowledged, though, that while it does feature as a concern in these official conversations, I would contend that reflection on it, as an ecumenical dilemma within these dialogues does not do justice to the weight of its problematic concern. I am only aware of the U.S. Reformed-Roman Catholic report of 1971 that gave some attention to women in the Church as a singular concern.

14. The irreversible decision was affirmed in John Paul II's encyclical Ut Unum Sint. That They May All Be One: On Commitment to Ecumenism (1995), §3, based on the direction Roman Catholicism took at the Second Vatican Council in Unitatis Redintegratio (Decree on Ecumenism), 21 November 1964.

15. See O'Gara, Margaret, The Ecumenical Gift Exchange (Collegeville: Liturgical Press, 1998), vii: "In ecumenical dialogue, each Christian communion brings one or many gifts to the dialogue table, and each receives riches from their dialogue partners as well. But in the ecumenical gift exchange, the gift giving 
input and feedback from other churches should ideally be offered in humility and graciously received as a precious gift. ${ }^{16}$

This is precisely what the Lima text underlined when it challenged churches in their discussions about the ordained ministry, that "Openness to each other holds the possibility that the Spirit may well speak to one church through the insights of another" (M54). As an ecumenical matter and concern, therefore, the position of Rome on women's ordination will (and should) inevitably generate reactions and responses from other churches. These must be received in the right spirit and manner by Rome (just as much as it should be given in the right spirit and manner by the other churches), since the Spirit may well speak to it through the insights of the 'separated brethren ${ }^{17}$. Herein lies a learning opportunity both for the Church of Rome as well as for the churches of the Reformation, which demands further exploration. ${ }^{18}$

\subsection{Assumption 4}

\section{The non-admission of women's ordination lies within the realm of papal dialogue}

The ecumenical churches regard the 1995 encyclical of John Paul II as his most remarkable papal letter. On May 25, 1995, the pope issued Ut Unum Sint ("That They May All Be One") in which he addressed one of the most sensitive of ecumenical topics, the papacy itself $(\S \S 4,88-97)$. While still acknowledging the legitimate place and role of the Petrine ministry in the church, he recognised that the manner of its exercise is always subject to criticism and improvement. In an unprecedented gesture he then invited his readers, including his 'separated brethren', to engage with him in a patient and fraternal dialogue about the exercise of the papal ministry and to recommend ways in which its outworking might conform more faithfully to the gospel (§§95-96). ${ }^{19}$

Anglican and Protestant churches find great anxiety and discomfort when they observe how the Vatican responds to diverse opinions among the faithful on matters such as women's ordination. Since a growing number of churches are increasingly studying the subject of the Petrine ministry in a new way, and since many of these bilateral discussions

enriches all of the partners, since we do not lose our gifts by sharing them with others. In fact, the gift exchange of ecumenism means a reception of gifts for which we have been prepared by repentance and hope."

16. In an insightful and practical article, "Toward the Sharing of Gifts" in Ecumenical Trends, Vol. 30, No. 7 (July/August 2001), Michael Kinnamon cites the WCC's first general secretary, Willem Visser't Hooft, who used to refer to the ecumenical movement as "essentially an attempt to manifest the economy of charismata" and that the WCC's purpose was "to bring the churches into such vital spiritual relations with each other that they joyfully discover how much they have to receive from each other and humbly prepare to use their own special gifts for the cause of the church in the whole world" (9).

17. A phrase from the Second Vatican Council documents, which talks more positively and respectfully about those not in full communion with Rome. Previously these faith communities were regarded as heretics, rather than fellow Christians, albeit separated.

18. The Lima text challenged the churches to take seriously the potential insights from other churches on ordained ministry, as well as capitalising on the opportunity to reflect in a fresh and frank manner on one's own understanding of ordained ministry: "All churches need to examine the forms of ordained ministry and the degree to which the churches are faithful to its original intentions. Churches must be prepared to renew their understanding and their practice of the ordained ministry" (M51).

19. The pope enquired: "Could not the real but imperfect communion existing between us persuade church leaders and their theologians to engage with me in a patient and fraternal dialogue on this subject [the Petrine ministry and its exercise], a dialogue in which, leaving useless controversies behind, we could listen to one another, keeping before us only the will of Christ for his church and allowing ourselves to be deeply moved by his plea 'that they may all be one ... so that the world may believe that you have sent me' (Jn. 17:21) (§96). 
are presently exploring the possibility of deeper communion with the Roman Catholic Church as well as with the pope himself, ${ }^{20}$ there is great concern and reservation when their observations seem to reveal a stereotypically authoritarian papacy, in such matters as women's ordination (cf. Manning 1999; Küng 2001; Wijngaards 2001). This does not do well for the reformed papacy to which John Paul II was claiming to commit himself at this time. Notwithstanding such continuing questions and reservations by the ecumenical churches vis-à-vis the Vatican leadership, we do have here a kind gesture to provide feedback on the manner in which the papal office exercises its ministry.

\subsection{Assumption 5}

The non-admission of women's ordination lies within the realm of a changing demographic profile of the church

It may be argued that the prevailing position of the Roman Catholic Church against women's ordination is kept intact by the overwhelming majority of Roman Catholics, which could be based on the changing demographic profile of the church. For today and tomorrow the gravity of Christianity is southward, and this certainly includes Roman Catholicism (see table below). ${ }^{21}$

\section{Catholics Worldwide 2025: A Projection ${ }^{22}$}

\begin{tabular}{lcc} 
& \multicolumn{2}{c}{$\begin{array}{c}\text { Number of Catholics } \\
\text { (in millions) } \\
\text { Year }\end{array}$} \\
Continent & 2000 & 2025 \\
Latin America & 461 & 606 \\
Europe & 286 & 276 \\
Africa & 120 & 228 \\
Asia & 110 & 160 \\
North America & 71 & 81 \\
Oceania & 8 & 11 \\
Total & 1056 & 1,362
\end{tabular}

What this means for the church is that conservative and traditional views may be further entrenched since generally "Southern Christians are far more conservative in terms of both beliefs and moral teaching. The denominations that are triumphing all across the global south are stalwartly traditional or even reactionary..." (Jenkins 2002:7). This goes to show, perhaps, why the issues - such as women's ordination - around which the traditionalist and conservative Vatican battles with its members in North America and Europe, in actual fact

20. For an overview of these emerging viewpoints and their underlying factors, see my article "The Promise of the Petrine Ministry: An Old Stumbling Block, A New Stepping-Stone" in Ned-Geref Teologiese Tydskrif, Vol. 43 No. 3 \& 4 (September \& December 2002), 487-98.

21. In his insightful book The Next Christendom: The Coming of Global Christianity, Philip Jenkins draws attention to the southernward shift of Christianity where, citing John Mbiti, "the centers of the church's universality [are] no longer in Geneva, Rome, Athens, Paris, London, New York, but Kinshasa, Buenos Aires, Addis Ababa and Manila." See Jenkins (2002:2).

22. Taken from Barrett, David B, et al, (2001), 12. 
present very little controversy, if at all concern, for many Roman Catholics in Africa, Asia and Latin America. "While the ordination of women may seem an essential point of justice to Westerners," explains Jenkins, "it is anathema for much of the emerging world." (2002:196).

On the other hand, though, culture is a dynamic reality of life, as we see even Africans, Latinos, and Asians fast changing on issues that were formerly unquestioned in their cultural experiences, not least because of the global village and technology that are now part and parcel of one's daily life. Irrespective of how the Two-Thirds world influences the Vatican, if at all, that they make up the greatest portion of the Roman Catholic Church is sufficient reason to listen to their concerns as well as their hopes in the area of such matters as women and leadership.

\section{Challenges in Offering an Ecumenical Contribution}

Having placed the prevailing Roman Catholic position of women's ordination in its wider ecumenical setting, coupled with those assumptions that make it possible and welcome to provide an ecumenical contribution on this matter, I am mindful of certain realities about the nature of the problem itself, which must be recognised before any meaningful consideration of the way forward can be realised. An ecumenical contribution can only be engaged once the various hindrances are identified, understood, and confronted. ${ }^{23}$ These presently prevail as areas requiring cognisance and further exploration by the ecumenical community.

\subsection{Relations with the Eastern Orthodox Church}

If the ecumenical community awaits theological movement from the Vatican on the issue of women's ordination, it will be a long and non-guaranteed wait. What should be understood is the ardent desire the Roman Catholic Church has towards the Eastern Orthodox Church in forging deeper communion. The latter church features prominently in the ecumenical hierarchy for Rome. On various occasions the pope has stated that he would give his life for unity with the East. In his 1995 encyclical letter he aptly referred to the Roman Catholic and Eastern Orthodox churches as the "two lungs" of the Church (\$54), implying that the churches have hitherto not been breathing too well.

In this light, therefore, we should take cognisance of the fact that here we are confronted with a seemingly insurmountable obstacle in our relations with Rome. Since these churches share the sacrament of orders, which cannot be said for Rome's relations with Anglican and Protestant Christianity, the Vatican cannot be expected to endanger any continued efforts with the East by compromising its stand on the exclusion of women to the ministerial priesthood.

\subsection{The Psyche of the Vatican}

A second challenge confronting the ecumenical churches in their attempts to see the Vatican surrender its longstanding view concerns various cultural-psychological factors of Rome. In this regard, John Paul II and Joseph Ratzinger reflect this accordingly if we are to understand why the present papacy is unashamedly authoritarian and autocratic. Here we have two strong personalities working together in managing the affairs of the Roman Catholic Church. What lies behind this psyche?

23. Here I am particularly indebted to Susan Rakocsy for her insightful remarks. 
For John Paul II, who has been accused of stifling the church for those who disagree with him, the reason may be discernible in what has been termed a "siege mentality" (cf. Christensen 1999). An anonymous source offered insight into the pontiff's thinking in a CNN website feature (ibid.):

Part of the problem is also his strength: He grew up in Poland where the church was persecuted by the Nazis and then by communism. The church was always under attack, and he developed a siege mentality. He has never really lived in a pluralistic, democratic society. ... So even after the fall of communism, the model of the church is still one that is under siege. But now it's by secularism, critics in the church, consumerism or relativism. And he responds with this kind of siege mentality, where the church is at war over these issues. And when you're at war, you don't have democracy. You don't debate what you're going to do.

\subsection{The Sacrament of Orders in the Ecumenical Churches}

For the pope and Ratzinger, they do not embrace the orders of ministry within the Anglican and Protestant churches as real orders. Where women priests and pastors emerge, the Vatican regards these as merely leaders of a congregation or that of a prayer group, as opposed to bearing the authority and sacramental character of the same orders within Roman Catholicism. This implies that the road to recognition of ministry by the Vatican is still a long way off in relation to the issue of women's ordination.

\section{Concluding Remarks}

The exclusion of women to the ministerial priesthood in the Roman Catholic Church is a teaching that demands further exploration within this church both for the sake of its own communion as well as for the ecumenical churches. At the same time, the inclusion of women to the ministerial priesthood in these other churches is also a teaching that demands renewed attention as these churches forge deeper communion with the Roman Catholic Church. It is important to be cognisant that the 'horse' on the table may be viewed in different ways from both perspectives. For Anglican and Protestant churches, the exclusion of women is that 'horse', but so, too, is the inclusion of women that 'horse' for the Roman Catholic Church. How the churches could proceed in their future attempts to be in communion with one another without compromising their theological integrity demands attention. 


\section{BIBLIOGRAPHY}

Allen, JL 2000. Cardinal Ratzinger: The Vatican's Enforcer of the Faith. New York: Continuum.

Baptism, Eucharist and Ministry, Faith and Order Paper No. 111. 1983. Geneva: WCC.

Barrett, DB et al (eds.) 2001. World Christian Encyclopedia, $2^{\text {nd }}$ ed. Oxford: Oxford University.

Christensen, J 1999. John Paul II: Conscience of the World www.cnn.com/SPECIALS/1999/pope/legacy.

Congregation for the Doctrine of the Faith, 1998. From "Inter Insigniores" to "Ordinatio Sacerdotalis": Documents and Commentaries. Washington: United States Conference of Catholic Bishops.

Jenkins, P 2002. The Next Christendom: The Coming of Global Christianity. Oxford: Oxford University.

Küng, H 2001. Women in Christianity. London: Continuum.

Manning, J 1999. Is the Pope Catholic? A Woman Confronts her Church. Ontario: Malcolm Lester Books.

O'Gara, M 1998. The Ecumenical Gift Exchange. Collegeville: Liturgical.

Paul VI, 1976. Inter Insigniores. www.geocities.com/papalencyclicals/Paul06/p6interi.htm John Paul II, 1994. Ordinatio Sacerdotalis. www.vatican.va/holy_father/john_paul_ii/apost_letters/documents/hf_jp_ii_apl_2205 1994_ordinatio-sacerdotalis_en.html.

John Paul II, 1995. Ut Unum Sint. That They May Be One: On Commitment to Ecumenism. Washington: United States Catholic Conference.

John Paul II, 1998. Ad Tuendam Fidem. http://www.cin.org/jp2/adtuen.html St Leger, M 2003. Women Unheard. The Tablet (11 January 2003).

Wijngaards, J 2001. The Ordination of Women in the Catholic Church: Unmasking a Cuckoo's Egg Tradition. New York: Continuum.

Wijngaards, J 2003. Hear it from the Women. The Tablet (18 January 2003). 